\title{
Serotonin Enhances the Excitatory Acetylcholine Response in the RB Cell Cluster of Aplysia californica
}

\author{
Linda K. Simmons and John Koester \\ Center for Neurobiology and Behavior, Columbia University, College of Physicians and Surgeons, and \\ The New York State Psychiatric Institute, New York, New York 10032
}

The $\mathbf{R B}$ cells, an identified cluster of serotonergic neurons in the abdominal ganglion of Aplysia californica, are excited by ACh. We have found that serotonin (5-HT) enhances the ACh responses recorded from the $\mathrm{RB}$ cells. The locus and specificity of the serotonergic interaction with the $\mathrm{ACh}$ response were analyzed using the conventional two-electrode voltage-clamp technique. We compared the current responses evoked in $R B$ cells by constant-current iontophoretic pulses of $\mathrm{ACh}$ in control solutions and in solutions containing various concentrations of 5-HT. Serotonin consistently enhances the ACh evoked response in a dose-dependent manner while simultaneously directly activating the $\mathrm{RB}$ cells by turning on a small steady-state inward current. The dose-response characteristics for the 5-HTmediated steady-state current differ, however, from those of the 5-HT-induced ACh response facilitation.

The $\mathrm{ACh}$ response enhancement appears to be an effect of 5-H'T upon $R B$ cell $A C h$ receptors since (1) the enhancement is present under conditions that eliminate presynaptic input, and (2) 5-HT is still capable of enhancing the iontophoretically evoked response when the AChE-resistant agonist carbachol is substituted for $\mathrm{ACh}$.

We tested other neurons in the Aplysia CNS exhibiting ACh evoked responses qualitatively similar to the $\mathrm{RB}$ cell $\mathrm{ACh}$ responses; 5-HT does not enhance the iontophoretically evoked ACh responses of these cells. Also, although the $R B$ cells are responsive to dopamine and histamine, these putative neurotransmitters do not enhance the $\mathrm{ACh}$ response.

Serotonin (5-HT) has an important function as a conventional, nonconventional, and modulatory neurotransmitter in Aplysia californica. Gerschenfeld and his colleagues have described a multiplicity of serotonergic receptor types in molluscan cells, including Aplysia (for a review, see Gerschenfeld et al., 1981). Some of these 5-HT receptors behave like conventional transmitter-gated channels: 5-HT-binding to receptors initiates a conductance increase to sodium (A and $\mathrm{A}^{\prime}$ responses), potassium (B response), and chloride (C response) (Gerschenfeld and Paupardin-Tritsch, 1974a, b). Two nonconventional synaptic responses to 5-HT application, conductance decreases to potassium ( $\alpha$ response) and to potassium and sodium ( $\beta$ response) were also initially described by Gerschenfeld and Paupardin-

Received Mar. 15, 1985; revised July 22, 1985; accepted July 24, 1985.

We wish to thank Lorna Role, Steven Siegelhaum, and Klaudiusz Weiss for critically reading early versions of the manuscript, and Cecil Oberbeck and Joanne Toran for typing the paper. The Howard Hughes Medical Institute generously supplied Aplysia from their Woods Hole facility. This work was supported by N.I.H. Grant NS 19328 to J.K. L.K.S. was supported by postdoctoral fellowships from the N.I.H. (NS 07038) and the Muscular Dystrophy Association.

Correspondence should be addressed to L.K.S. at Center for Neurobiology and Behavior, Columbia University and New York State Psychiatric Institute, 722 West 168th St., New York, NY 10032.

Copyright (C) 1986 Society for Neuroscience $0270-6474 / 86 / 030774-08 \$ 02.00 / 0$
Tritsch (1974a, b). Recently, Walsh and Byrne (1985) analyzed a 5-HT-initiated decreased conductance to potassium in Aplysia L14 motor neurons, which may be mediated by cyclic AMP.

Serotonin also modulates several different types of voltagegated channels in the Aplysia nervous system. Kandel, Schwartz, and their colleagues have demonstrated that 5-HT induces a long-lasting closure of a unique type of potassium channel in abdominal ganglion sensory cells (Klein et al., 1982; Siegelbaum et al., 1982) that is mediated by a cyclic AMP-dependent phosphorylation cascade (Bernier et al., 1982; Brunelli et al., 1976; Castellucci et al., 1980, 1982; Shuster et al., 1985). Pollock et al. (1985) have recently shown that 5-HT closes a similar type of potassium channel in pleural ganglion sensory cells. This effect is also mediated by a cyclic AMP-dependent process. Levitan and his colleagues have described a 5-HT-induced increase in membrane potassium conductance in cell $\mathrm{R} 15$, which is mediated by a cyclic AMP-dependent protein phosphorylation (Adams and Levitan, 1982; Drummond et al., 1980). Finally, Pellmar and Carpenter have described a 5-HT-dependent opening of voltage-gated calcium channels in the RB and LB cell clusters (Pellmar, 1984; Pellmar and Carpenter, 1980) that does not appear to be mediated by a cyclic AMP-dependent mechanism (Pellmar, 1981).

Serotonin also modulates the activity of buccal (Ram et al., 1981; Weiss et al., 1978) and heart (Liebeswar et al., 1975) muscle in Aplysia, with cyclic AMP mediating the effect of 5-HT in both muscle tissues (Mandelbaum et al., 1979; Sawada et al., 1984; Weiss et al., 1979).

We have extended the analysis of the modulatory role of 5-HT in the Aplysia CNS by describing a novel serotonergic modulation of the excitatory cholinergic receptors in the RB cell cluster. The RB cells are a homogeneous cluster of serotonergic cells (Eisenstadt et al., 1973; Goldstein et al., 1984; Kistler et al., 1985) located in the caudal right quadrant of the dorsal abdominal ganglion. One identified cell of this cluster, the $\mathrm{RB}_{\mathrm{HE}}$ neuron, increases heart activity during food arousal (Koch et al., 1984). The RB cells receive dircet input from the cholinergic neurons L10, L24, and Int XIII (Kandel et al., 1967; Segal and Koester, 1982). Iontophoretic application of $\mathrm{ACh}$ to $\mathrm{RB}$ somas elicits an excitatory response due to $\mathrm{ACh}$ receptor-gating of channels that are relatively nonselectively permeable to cations (Ascher et al., 1978; Simmons, 1983). In this paper we demonstrate that bathapplied 5-HT selectively enhances the response of the RB cells to iontophoretic application of ACh. A preliminary report of these results has already been presented (Simmons, 1984).

\section{Materials and Methods}

\section{Animals}

Aplysia californica, ranging from 20 to $100 \mathrm{gm}$, were obtained from various sources: Sea Life Supply (Sand City, CA), Marinus (Westchester, 
CA), Pacific Biomarine (Venice, CA), and from eggs raised at the mariculture facility at the Howard Hughes Medical Institute Marine Biological Laboratory (Woods Hole, MA). The results discussed in this paper were consistently observed in all Aplysia, regardless of their origin. The animals were maintained in commercially produced artificial seawater (ASW) (Instant Ocean, Aquarium Systems, Mentor, $\mathrm{OH}$ ) at $15^{\circ} \mathrm{C}$.

\section{Dissection}

Cholinergic receptors of the RB cell cluster, cell R15, unidentified cells in the $\mathrm{LC}$ cell cluster in the abdominal ganglion, and the anterior cell cluster of the left pleural ganglion were investigated in this study. The cells and cell clusters were identified using the criteria outlined by Frazier et al. (1967), Koester and Kandel (1977), and Ascher (1972). After pretreating the ganglia in $0.5 \%$ glutaraldehyde in ASW for $30-45 \mathrm{sec}$ to inactivate the sheath muscle, the surface cells were exposed by desheathing. In some experiments, the RB cell clusters were tied off (using fiber strands of unwaxed dental floss) and separated from the rest of the ganglion in order to facilitate space-clamping and to eliminate spontaneous synaptic input.

\section{Solutions and perfusion system}

The desheathed ganglia were pinned in Sylgard- (Dow Corning, Midland, MI) containing dishes and maintained in an open, continuously perfusing system of ASW. Inflow was gravity controlled while the effluent was removed by suction. Temperatures ranged from 17 to $22^{\circ} \mathrm{C}$ across preparations. A Cambion (Cambridge, MA) temperature-controlled Peltier plate held the temperature variation within preparations to $\pm 0.5^{\circ} \mathrm{C}$. The bath volume was $1.5 \mathrm{ml}$ with a turnover rate between $1 \mathrm{ml} / 7$ and $1 \mathrm{ml} / 30 \mathrm{sec}$ (across preparations). In order to determine the turnover kinetics of the perfusion system, we conducted experiments introducing a dyc into the perfusatc. After infusing the dye, the perfusate was periodically sampled using a Beckman (Palo Alto, CA) spectrophotometer. The dye was first observed in the bath within the range of $20 \mathrm{sec}(1 \mathrm{ml} / 7 \mathrm{sec})$ to $3.5 \mathrm{~min}(1 \mathrm{ml} / 30 \mathrm{sec})$ after the start of infusion. At the fastest fluid turnover rate, a $95 \%$ change of the bath volume required approximately $2 \mathrm{~min}$, while the slowest turnover rate required $10 \mathrm{~min}$. The majority of these experiments were conducted at an intermediate perfusion rate $(1 \mathrm{ml} / 12-20 \mathrm{sec})$, with new solutions reaching the bath in 1-3 min, initiating a $95 \%$ change in bath volume in 4-8 min.

Normal ASW contained (in $\mathrm{mm}$ ) $\mathrm{NaCl}, 460 ; \mathrm{KCl}, 10 ; \mathrm{CaCl}_{2}, 11$; $\mathrm{MgCl}_{2}, 55$; and HEPES buffer, 10 (titrated to $\mathrm{pH} 7.4$ with $\mathrm{NaOH}$ ). In some experiments we used a high-divalent cation ASW consisting of (in mM) NaCl, 317; KCl, $10 ; \mathrm{CaCl}_{2}, 33 ; \mathrm{MgCl}_{2}, 165$; and HEPES

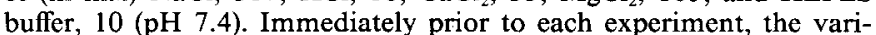
ous putative neurotransmitters and drugs (all from Sigma Chemical Co., St. Louis, MO) were mixed into normal ASW at the required concentrations for perfusion into the bath. These included 5-hydroxytryptamine creatinine sulfate (serotonin) (5-HT), 2(4-imidazolyl)ethylamine dihydrochloride (histamine), 3-hydroxytyramine (dopamine), and creatinine sulfate. Serotonin was maintained in an acidic stock solution $\left(2 \times 10^{-2} \mathrm{M} 5\right.$-HT in $10^{-1} \mathrm{M}$ acetic acid) and diluted to the desired concentration in ASW. For concentrations higher than $10^{-4} \mathrm{M} 5-\mathrm{HT}$, the transmitter was directly dissolved in ASW. Acetylcholine chloride and the cholinergic agonist carbamylcholine chloride (carbachol) (both from Sigma Chemical Co.) were dissolved to a $1 \mathrm{M}$ concentration in deionized water for iontophoresis.

\section{Electrophysiology}

The individual cells were voltage-clamped (Dagan, Minneapolis, $\mathrm{MN}$ ) using two shielded electrodes containing $2.5 \mathrm{M} \mathrm{KCl} \mathrm{(2-5} \mathrm{M \Omega ).} \mathrm{One}$ electrode monitored the membrane potential of the cell, while the second electrode passed the current necessary to maintain the command holding potential. A third electrode, the iontophoretic micropipette containing ACh or carbachol (20-40 M $)$, was connected to a constant-current generator, which provided the constant, inward-bucking current $(10$ $30 \mathrm{nA}$ ) needed to prevent $\mathrm{ACh}$ diffusion from the pipette. This pipette was visually positioned in close proximity to the cell body. Iontophoretic ejection of ACh was elicited by outward constant-current pulses of 2.54 scc duration (unless otherwise noted), with amplitudes ranging from 15 to $40 \mathrm{nA}$. The iontophoretic currents, clamp currents, and voltage traces were displayed on a Gould (Cleveland, $\mathrm{OH}$ ) chart recorder and stored on an A. R. Vetter (Rebersburg, PA) FM tape recorder for further analysis.

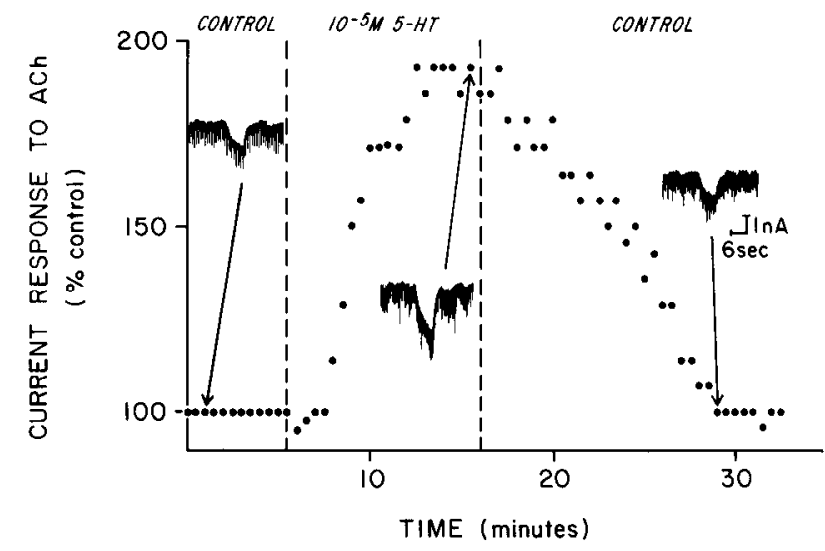

Figure 1. Serotonin-enhanced $\mathrm{ACh}$ response in a representative $\mathrm{RB}$ cell. The RB cell was clamped to $-60 \mathrm{mV}$ and an iontophoretic pipette containing $1 \mathrm{M}$ ACh positioncd ncxt to the ccll body surface. Constantcurrent pulses of ACh were presented every $30 \mathrm{sec}$. The amplitudes of the ACh-induced clamp current responses were measured as the distance from the baseline current just before the response to the most negative value of current during the response. Each response, normalized to the mean of the control responses (defined as $100 \%$ ), is plotted as a function of time for the initial control, experimental $\left(10^{-5} \mathrm{M} 5-\mathrm{HT}\right)$, and washout periods. Insets, Current traces illustrating the response of the cells to iontophoretic ACh application in the different solutions (inward current is down). The slow downward trace is the ACh response. The fast inward current transients are due to spontaneous excitatory synaptic input. The ACh response almost doubles with 5-HT in the bath, and when returned to control ASW, reverses to control values.

\section{Results}

\section{Serotonergic modulation of the ACh response in} voltage-clamped $R B$ cells

The $\mathrm{RB}$ cells were clamped at holding potentials between -50 and $-60 \mathrm{mV}$ (these cells normally exhibit a resting membrane potential of -40 to $-45 \mathrm{mV}$ in control ASW). Iontophoretic application of ACh onto voltage-clamped RB somas elicits a purely excitatory response, an inward current caused by the opening of ion channels that are permeable to cations. Constantcurrent pulses of ACh were presented every $30 \mathrm{sec}$ while the preparation was being perfused with control and various experimental ASW solutions. Cells that did not display a stable ACh response in control ASW solutions were rejected. The slow exponential rise and decay of the $\mathrm{ACh}$ current responses in these experiments reflect the slow diffusion of $\mathrm{ACh}$ to and from cell body cholinergic receptors (see raw data insets of Fig. 1). In this paper we will use the term "receptor" to include both the AChbinding component and the coupled ion channel.

Figure 1 depicts a representative experiment showing the time course and magnitude of the $\mathrm{ACh}$ response enhancement in response to $10^{-5}$ M 5-HT. The peak ACh-induced currents were measured from the holding current baseline recorded prior to each ACh pulse. The ACh responses have been normalized to the $\mathrm{ACh}$ responses evoked during the initial control period (defined as $100 \%$ ). In this experiment, with a bath turnover rate of $1 \mathrm{ml} / 20 \mathrm{sec}$, approximately $2.5 \mathrm{~min}$ after the addition of 5-HT there is an augmentation in the amplitude of the response to ACh. The enhancement becomes maximal 6-7 min after infusing 5-HT/ASW, with the ACh response returning to control values after 14-15 min in control ASW. The insets show raw data current records observed in the initial control, experimental, and washout conditions. The slow downward traces are the response of the cell to $\mathrm{ACh}$; the fast activity superimposed upon the slow traces reflects spontaneous excitatory synaptic input.

Since a creatinine sulfate salt of 5-HT was used in these ex- 


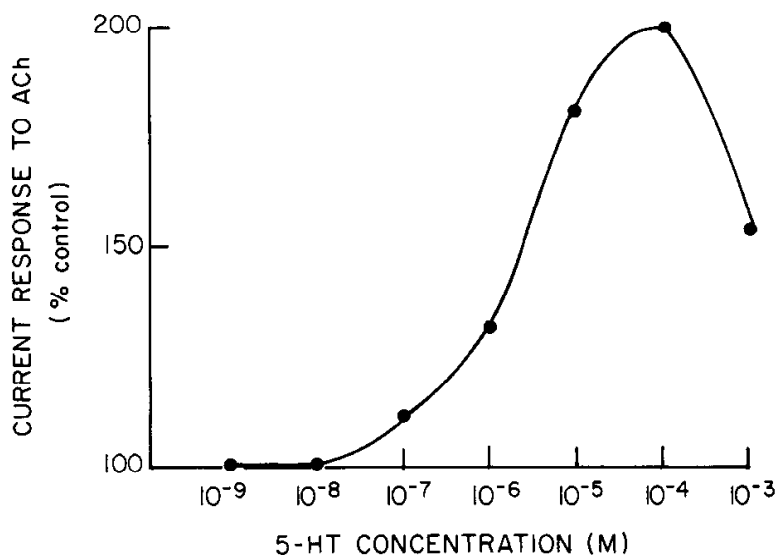

Figure 2. Dose-response characteristics of the 5-HT-mediated ACh response enhancement in an RB cell. This cell was voltage-clamped to $-60 \mathrm{mV}$. The frequency of the ACh iontophoretic pulses was 0.033 $\mathrm{Hz}$. Each data point is the mean of four time points after the $\mathrm{ACh}$ response had peaked in the respective 5-HT/ASW concentrations. SEM bars are within the filled circle symbols. The 5-HT-induced enhancement of the ACh response has a threshold between $10^{-8}$ and $10^{-7} \mathrm{M} 5$ $\mathrm{HT}$, saturates around $10^{-4} \mathrm{M}$, and is depressed at $10^{-3} \mathrm{M} 5-\mathrm{HT}$. The curve was fitted by eye.

periments, control experiments were required to determine whether the $\mathrm{ACh}$ response modulation was due solely or in part to the creatinine sulfate complex. We determined that creatinine sulfate does not produce the $\mathrm{ACh}$ response enhancement observed with 5-HT (data not shown).

The dependence of the enhancement of the $\mathrm{ACh}$ response on 5-HT concentration is illustrated in Figure 2. These results are from a representative experiment. Each point is the mean of four data points observed several minutes after the $\mathrm{ACh}$ response had stabilized in the different 5-HT/ASW concentrations. A higher 5-HT concentration was introduced every 20 $30 \mathrm{~min}$. The threshold for the 5-HT-induced enhancement of the ACh response occurs between $10^{8}$ and $10^{-7} \mathrm{M} 5-\mathrm{HT}$. The enhancement saturates around $10^{-4} \mathrm{M} 5-\mathrm{HT}$ and decreases as the 5-HT concentration increases. Obtaining dose-response curves by serially adding increasing concentrations of 5-HT was possible because, unlike the typical neuronal response to prolonged exposure of a neurotransmitter, the 5-HT-induced augmentation of the ACh response did not desensitize with low concentrations of 5 -HT (less than $5 \times 10^{-5}$ to $5 \times 10^{-4} \mathrm{M}$ across preparations). Preliminary experiments showed that, once the ACh response had attained its maximum enhancement in the experimental solution, there was no desensitization (or dccrcase in the 5-HT-induced enhancement) for periods up to $60 \mathrm{~min}$. For higher concentrations of 5-HT, however, the initial enhancement of the $\mathrm{ACh}$ response was followed by a relative decline to a steady-state level of enhancement. In Figures 2 and 3 , the enhancement of the ACh response at $10^{-3} \mathrm{M} 5-\mathrm{HT}$ was determined after the $\mathrm{ACh}$ response had stabilized for several minutes during the relatively depressed phase.

The perfusion rates utilized in these experiments were slow enough to blur the time boundary between a change in the bath concentration of 5-HT and the onset and development of ACh response modulation. Both the onset latency and the rate of 5-HT-induced ACh response enhancement could be explained by free diffusion and mixing of 5-HT in the bath. The recovery times necessary to reverse the $\mathrm{ACh}$ response enhancement during washout in control ASW depended upon the concentration of 5-HT: the higher the concentration, the longer the recovery rate. This slow reversal during washout could be a function of removal of 5-HT from inaccessible regions of the ganglion. If the washout of 5-HT were rate-limiting, this would explain the

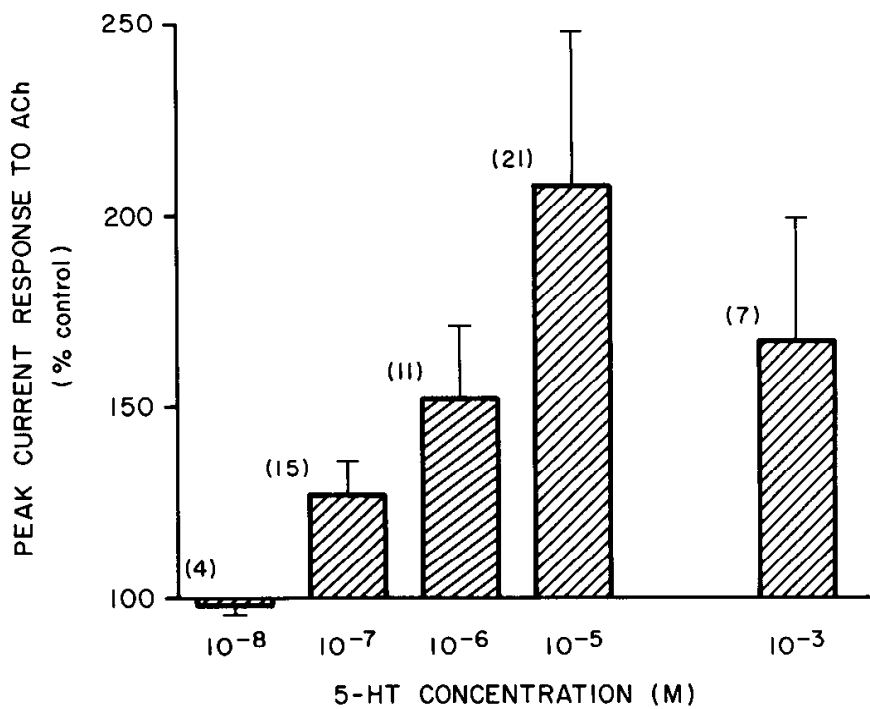

Figure 3. Summary histograms with SEM bars illustrating the effect of various concentrations of 5-HT on RB cell responses to ACh across experiments. The numbers depict the number of cells studied at each 5-HT concentration.

longer time required for reversing the effects of higher concentrations of 5-HT.

Serotonin enhances the RB cell ACh response in a highly reproducible fashion; in 78 out of 79 RB cells (64 out of 65 Aplysia), 5-HT $\left(10^{-7}-10^{-3} \mathrm{M}\right)$ significantly enhanced the iontophoretically evoked ACh response by a factor of 1.14-3.04 $(p<0.001$; two-tailed $t$ test). Figure 3 is a summary graph illustrating the modulatory effect of five concentrations $\left(10^{-8}\right.$, $10^{-7}, 10^{-6}, 10^{-5}$, and $\left.10^{-3} \mathrm{M}\right)$ of 5-HT upon the responses of $\mathrm{RB}$ cells to iontophoretic ACh across ganglia. Despite a large degree of variability across preparations, the enhancement at low concentrations of 5-HT and the relative decline of the enhancement at higher concentrations of 5-HT is still obscrved across ganglia.

\section{Serotonin activates a small, steady-state inward current} with dose-response characteristics different from those of the $A C h$ response enhancement

In unclamped RB cells, 5-HT directly initiates a membraneconductance change, producing a depolarization that leads to excitation. Pellmar (1984) has shown that one underlying component of this 5-HT-induced excitation is the opening of calcium channels. Using $2 \mathrm{sec}$ command pulses in voltage-clamped RB cells, Pellmar demonstrated that the 5-HT-mediated conductance change is voltage-dependent, requiring that the cell membrane be depolarized to at least $-40 \mathrm{mV}$.

In our voltage-clamp experiments, with clamp-holding potentials between -50 and $-60 \mathrm{mV}$ for the duration of the experiments (up to several hours), we sometimes observed a small net inward current during perfuson with 5-HT/ASW. The enhanced $\mathrm{ACh}$ response was superimposed upon this $5-\mathrm{HT}$-induced steady-state current. When compared with the 5-HT-sensitive ACh response modulation, however, the 5-HT-induced steadystate inward current displayed a different concentration dependence. The net inward current was observed only once in 26 experiments in response to $10^{-6}$ and/or $10^{-7} \mathrm{M} 5-\mathrm{HT}$, concentrations that reliably produced an enhanced $\mathrm{ACh}$ response. In all 25 experiments in which the concentration of bath-applied 5-HT was $10^{-5}, 10^{-4}$, and/or $10^{-3} \mathrm{M}$, a dose-dependent steadystate inward current (ranging from 0.5 to $6.0 \mathrm{nA}$ ) coincided with the $\mathrm{ACh}$ response modulation.

Figure 4 illustrates a representative long-term experiment 


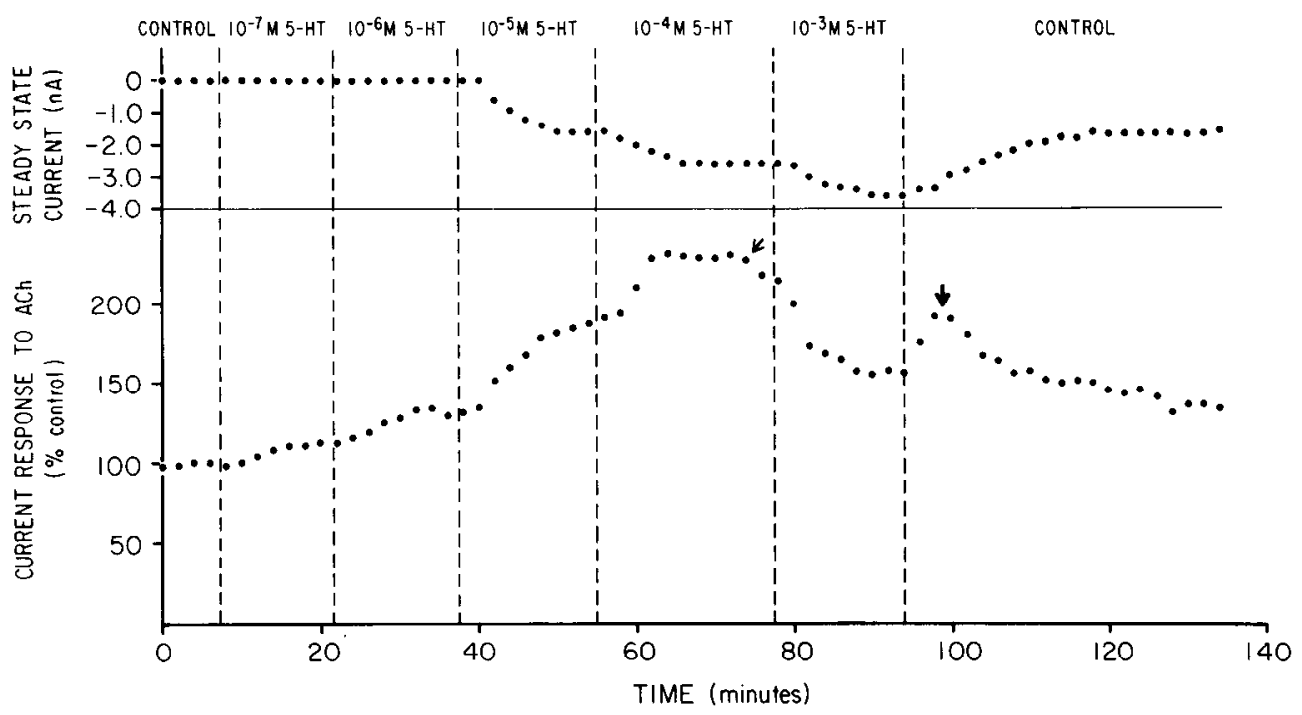

Figure 4. Long-term experiment illustrating the divergent concentration dependencies of the 5-HT-mediated steady-state inward current and the 5-HT-dependent ACh response enhancement in an RB cell. The holding potential was $-60 \mathrm{mV}$. Constant-current ACh pulses were presented every $30 \mathrm{sec}$. The $\mathrm{ACh}$ response and the steady-state holding current were monitored simultaneously while infusing increasing concentrations of 5-HT into the bath. Each point is the mean of four time points $(2 \mathrm{~min})$, with the steady-state current being measured immediately prior to each $\mathrm{ACh}$ response. Inward current is depicted downward. The ACh response is facilitated at $10^{-7}$ and $10^{-6} \mathrm{M}$-HT, whereas the steady-state inward current does not appear until $10^{-5} \mathrm{M}$ 5-HT. The two 5-HT-mediated processes diverge again in $10^{-4} \mathrm{M}$ 5-HT (small arrow). The continued enhancement of the steady-state inward current coincides with a depression of the ACh response potentiation. The ACh response potentiation shows more depression in $10^{-3} \mathrm{M} 5-\mathrm{HT}$. With the addition of control ASW, the ACh response becomes temporarily enhanced before returning toward control values (see large arrow), while the inward current demonstrates a smooth reversal towards control.

showing the lack of correlation between the amount of $\mathrm{ACh}$ response enhancement and the magnitude of the inward current as a function of the 5-HT concentration. The RB cell was clamped at $-60 \mathrm{mV}$, and increasing concentrations of 5-HT were perfused into the bath. Both the steady-state holding current and the $\mathrm{ACh}$ response were monitored simultaneously. Each point is the mean of four time points (the steady-state current was measured immediately prior to each $\mathrm{ACh}$ response). The $A C h$ response enhancement is observed exclusively at $10^{-7}$ and $10^{-6}$ м 5-HT. At $10^{-5}$ м 5-HT, the steady-state inward current appears. The $\mathrm{ACh}$ response enhancement and the inward current are still visible when $10^{-4} \mathrm{M} 5-\mathrm{HT}$ is perfused into the bath. During the incubation in $10^{-4}$ м $5-\mathrm{HT}$, however, the $\mathrm{ACh}$ response enhancement begins to show the charactcristic decline, while the steady-state current continues to increase. During the initial phase of washout in control ASW, the ACh response is momentarily greater, presumably because of the removal of the depressant effects of high concentrations of 5-HT, before returning towards control valucs. Meanwhile, the steady-state current declines along a smooth time course towards control (see large arrow). Incubation in high concentrations of 5-HT for such long periods necessitated a very long washout period (on the order of hours) to return to original control values; the cell usually died before a complete return could be observed. The divergence between the steady-state current and the $\mathrm{ACh}$ response enhancement with high concentrations of 5-HT was not observed consistently. In $70 \%$ of the experiments, concentrations of 5-HT that initiated a decline in the ACh response enhancement also produced a smaller steady-state inward current. This inward current subsequently became temporarily larger during washout in control ASW before disappearing.

\section{Serotonin modulates the $A C h$ response by affecting the cholinergic receptor}

With a protocol involving bath application of 5-HT, it is conceivable that 5 -HT acts via an unkown interneuron, which in turn modulates the $\mathrm{RB}$ cell $\mathrm{ACh}$ response. We found, however, that 5-HT consistently enhanced ACh responses when (1) the preparations were maintained in high-divalent-cation ASW to eliminate possible interneuronal input, and (2) the RB cell cluster was tied off and separated from the rest of the ganglion, thereby removing presynaptic input. Figure 5 illustrates the continued presence of the 5-HT-mediated enhancement of the ACh response in tied-off RB cells and in RB cells maintained in highdivalent-cation ASW for the duration of the experiment. In Figure $5 A$, addition of $10^{-5} \mathrm{M} 5-\mathrm{HT}$ produces the characteristic enhancement of the ACh response. The steady-state inward current (see Fig. 4) is present in high-divalent-cation ASW (the dashed line represents the current baseline of the voltage-clamped cell in control ASW). Figure $5 B$ illustrates the enhancement observed when $10^{-6} \mathrm{M} 5$-HT is added to a representative tiedoff $\mathrm{RB}$ ccll. The constant-current $\mathrm{ACh}$ pulses were $61 \mathrm{sec}$ in
A
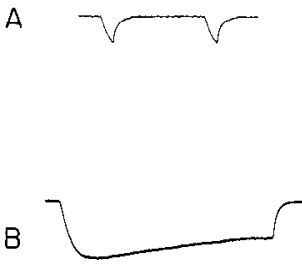

2
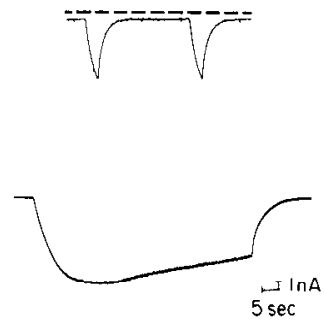

Figure 5. Serotonin enhances the ACh response in $\mathrm{RB}$ cells maintained in a high-divalent ASW and in tied-off RB cells. $A$, Representative raw data for ACh responses evoked in control ASW ( $(1)$ and in ASW containing $10^{-5} \mathrm{M} 5-\mathrm{HT}$ (2). The dashed line in (2) is the control holdingcurrent baseline. The steady-state net inward current response to 5-HT is still present in cells incubated in a high-divalent ASW that depresses interneuronal activity. The representative raw data in $B$ are $A C h$ responses elicited by $61 \mathrm{sec}$ duration iontophoretic current pulses in control ASW (1) and in $10^{-6}$ M 5-HT/ASW (2) in tied-off cells. The ACh response is enhanced, but $10^{-6} \mathrm{M} 5-\mathrm{HT}$ is below threshold for the steadystate inward current (see text). 


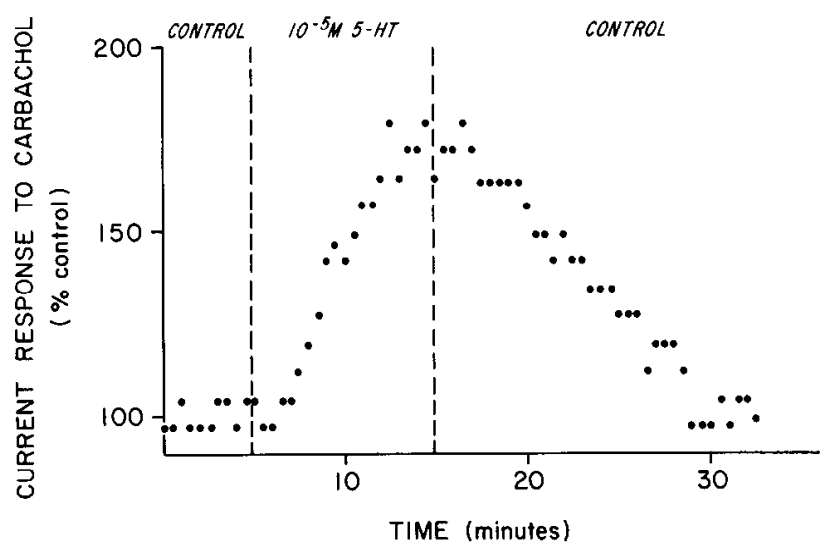

Figure 6. Serotonin $\left(10^{-5} \mathrm{M}\right)$ enhances the excitatory response to carbachol iontophoresis in RB cells. In this experiment the RB cell was clamped al. $-60 \mathrm{mV}$, and the iontophoretic pulses of carbachol wcrc presented every $30 \mathrm{sec}$.

duration. In this experiment, $10^{-6} \mathrm{M} 5-\mathrm{HT}$ is below threshold for the steady-state inward current (see Fig. 4). Using tied-off cells also reduces the possibility that the enhanced $\mathrm{ACh}$ response in 5-HT/ASW might be due to the interaction of ACh with membrane that is under poor clamp control.

Serotonin may enhance the $\mathrm{ACh}$ response by interacting with a molecular component that is closely associated with the $\mathrm{ACh}$ receptor. For example, rat brain AChE activity is inhibited by 5-HT (Fujimoto, 1976). Figure 6 shows a representative experiment demonstrating that the responses of $\mathrm{RB}$ cells to iontophoretic application of carbachol, an AChE-resistant cholinergic agonist, continue to show enhancement in the presence of bathapplied 5-HT.

\section{Enhancement of the $A C h$ response in $R B$ cells is specific to 5-HT}

RB cells inhibited by bath application of other putative neurotransmitters, such as dopamine (Ascher, 1972) and histamine (unpublished data). Infusing up to $10^{-4} \mathrm{M}$ dopamine or histamine into the bath did not increase the response to iontophoretic

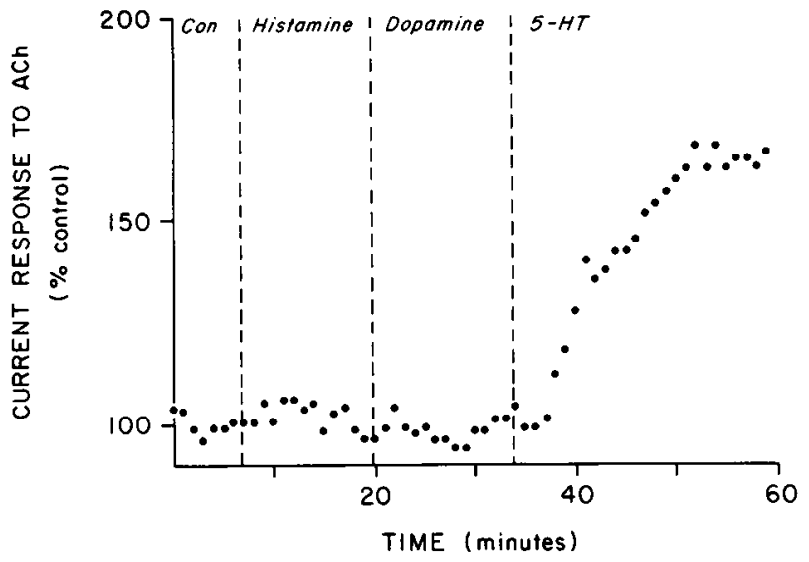

Figure 7. Dopamine and histamine do not mimic the 5-HT-induced facilitation of the ACh response in RB cells. The membrane potential of this RB cell was held at $-60 \mathrm{mV}$. Iontophoretic pulses of ACh were presented every $30 \mathrm{sec}$. Each point is the mean of two data points (1 $\mathrm{min})$. The ACh responses are normalized to current responses evoked by ACh in control ASW (Con). Dopamine $\left(10^{-5} \mathrm{M}\right)$ and histamine $\left(10^{-5}\right.$ M) do not change the $\mathrm{ACh}$ response, but $2 \times 10^{-6} \mathrm{M} 5-H T$ produces the characteristic facilitation of the $\mathrm{ACh}$ response.

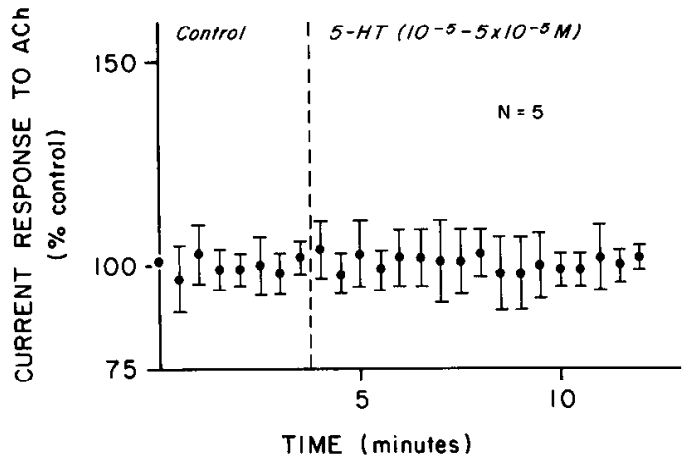

Figure 8. Serotonin does not modulate the excitatory ACh response in $\mathrm{R} 15$ cells. This summary figure shows the effect of $10^{-5}-5 \times 10^{-5}$ M 5-H'T on the ACh response in cell R15. The membrane potentials were held between -50 and $-60 \mathrm{mV}$. Iontophoretic pulses of $\mathrm{ACh}$ were presented every $30 \mathrm{sec}$. Each point represents the mean and SEM of five $\mathrm{R} 15$ cells in control and experimental conditions.

pulses of $\mathrm{ACh}$. Figure 7 illustrates a representative experiment showing the effects of $10^{-5} \mathrm{M}$ dopamine and $10^{-5} \mathrm{M}$ histamine on an RB cell that is voltage-clamped at $-60 \mathrm{mV}$. At this holding potential, both transmitters elicit a steady-state outward current that inhibits the unclamped cell (data not shown), but the ACh response is unchanged. Subsequent addition of $2 \times 10^{-6} \mathrm{M} 5$ HT produces the characteristic enhancement of the ACh response.

Serotonergic enhancement of the ACh response is not a universal feature of Aplysia excitatory

$A C h$ receptors

In the Aplysia CNS, there are cells other than RB cells that exhibit the same type of pure excitatory response to somatic ACh iontophoresis, presumably because the same type of receptor is being activated. One such cell is R 15 , a large peptidergic neurosecretory cell located in the dorsal abdominal ganglion, and usually partially surrounded by the RB cell cluster (Frazier et al., 1967). Levitan and his colleagues have demonstrated that 5-HT increases a distinct potassium conductance, thereby changing the bursting characteristics of the cell (Drummond et al., 1980). Figure 8 is a summary figure illustrating the effects of $10^{-5} \mathrm{M}$ to $5 \times 10^{-5} \mathrm{M} 5$-HT on the evoked responses to iontophoretically applied $\mathrm{ACh}$ in five $\mathrm{R} 15$ cells. As was previously reported by Tremblay et al. (1976), 5-HT does not change the response of the R15 cells to iontophoretically applied $\mathrm{ACh}$.

We tested other Aplysia neurons with excitatory ACh responses for possible serotonergic modulation. Cells in the left anterior pleural ganglion display a pure excitatory response to iontophoretic ACh application (Ascher, 1972). In our experiments, with the holding-clamp potential between -55 and -60 $\mathrm{mV}$, up to $10^{-4} \mathrm{M} 5-\mathrm{HT}$ did not change the response of the cells to iontophoretic application of $\mathrm{ACh}$. There was, however, variation in the direct responses of the anterior cells to 5-HT. In some instances, 5-HT turned on an inward current; on other occasions, 5-HT initiated a steady-state outward current. These results are consistent with other evidence that cells of the anterior pleural cell cluster are somewhat heterogeneous in their properties (Kehoe, 1972). Unidentified cells in the abdominal ganglion LC cell cluster with excitatory responses to iontophoretic ACh application were also tested for possible 5-HT modulation of the $\mathrm{ACh}$ response. As with the $\mathrm{RB}$ cells, serotonin consistently activated an inward current (clamp potential at -60 $\mathrm{mV}$ ), which elicited firing in the unclamped cell. But, unlike its effect on the RB cells, 5-HT did not modulate the ACh response of the LC neurons (data not shown). 


\section{Discussion}

In vertebrates and invertebrates, 5-HT modulates the efficacy of CNS and PNS cholinergic synapses in a variety of ways. Studies show that 5-HT can inhibit or facilitate ganglionic transmission by depressing or enhancing presynaptic release (Dun and Karczmar, 1981; North et al., 1980; Wallis and Woodward, 1975). Serotonin can also indirectly modulate sympathetic ganglion transmission by increasing the membrane conductance of the postsynaptic cell to sodium and potassium, thereby "shunting" the cholinergic potential (Dun and Karczmar, 1981), or facilitating the ACh potential by decreasing membrane conductance (probably to potassium) (Dun and Ma, 1984; Dun et al., 1984).

A third means of modulation involves a 5-HT-dependent depression of subsynaptic cholinergic receptor sensitivities in the endplate and nonsynaptic regions of voltage-clamped frog sartorius muscle (Akasu et al., 1983) and on voltage-clamped frog sympathetic ganglion cells (Akasu et al., 1981; Koketsu et al., 1982). Akopyan et al. (1980) have demonstrated that 5-HT depresses the chloride-dependent responses elicited by bathapplied $\mathrm{ACh}$ in isolated, voltage-clamped neurons of the mollusk, Limnaea stagnalis. In this paper we show that 5-HT selectively enhances the cation-dependent response of voltageclamped Aplysia RB cells to iontophoretic ACh application.

ACh activates three pharmacologically distinct receptors in Aplysia. The "fast" excitatory and inhibitory receptors are permeable to cations and chloride, respectively. The "slow" inhibitory receptors are selective for potassium (Kehoe, 1972). The cells of the RB cluster express the "fast" excitatory cholinergic receptors on their somas and on their physically distant synaptic regions (Segal and Koester, 1982). Bath-applied 5-HT facilitates the excitatory response of the RB cells to ACh. This potentiation is specific for 5-HT; other putative transmitters such as dopamine and histamine activate RB cell dopaminergic and histaminergic receptors without producing a concomitant increase in ACh response. Serotonin appears to be producing its effect by modulating the ACh receptor, since (1) the modulation is present both in cells bathed in high-divalent cation ASW and in tied-off cells, thereby ruling out the presence of an unidentified 5-HT-sensitive interneuron that might enhance RB cell cholinergic receptor activity, and (2) potentiation of carbachol-evoked excitatory responses also occurs with bath-applied 5-HT, eliminating the possibility that $5-\mathrm{HT}$ is indircetly facilitating the $\mathrm{ACh}$ response by inactivating $\mathrm{AChE}$.

This serotonergic modulation of $\mathrm{ACh}$ receptor activity is not a common property of all Aplysia cells with excitatory cholinergic receptors. The other cells tested-R15, unidentified anterior pleural cells, and unidentificd LC cells-have excitatory ACh receptors that are not modulated by bath-applied 5-HT. If there is only one type of excitatory cholinergic receptor, as the pharmacological studies suggest, these results imply that there is something intrinsic to RB cells that mediates the 5-HTdependent enhancement of the ACh response. Possibly, however, there is more than one type of excitatory ACh receptor in Aplysia only, one of which is modulated by $5-\mathrm{HT}$. A quantitative analysis of the conductance and kinetic characteristics of excitatory ACh-sensitive channels in different cells might unmask the different types.

The dose-response curves demonstrate a well-behaved relationship between 5-HT concentration and degree of ACh response facilitation. Drawing any conclusions regarding the shape of the dose-response curve is impossible, however, without knowledge of certain parameters, i.e., distance of the iontophoretic pipette from the cell surface, geometric configuration of the cell body, topographic receptor distribution, the $\mathrm{ACh}$ concentration profile, etc. (see, for example, Dreyer et al., 1978). At high 5-HT concentrations $\left(5 \times 10^{-5}\right.$ to $\left.10^{-3} \mathrm{M}\right)$, the dose- response curve saturates and shows a downward trend (see Fig. 2 ). The relative depression of the $\mathrm{ACh}$ response enhancement that occurs with increasing 5-HT concentrations may signal the introduction of a second, specific inhibitory process. A likely alternative, given these nonphysiological concentrations, is that 5-HT alters cholinergic receptor activity nonspecifically, e.g., by blocking the ACh-sensitive channels.

With the relatively slow methods of 5-HT bath application used in these experiments, the perfusion rate appears to determine the onset latency of the modulated ACh response and the rate of enhancement in 5-HT/ASW. This does not eliminate the possibility that a time-dependent second messenger is involved. For example, activation of the abdominal ganglion facilitator neurons induces a threefold increase in sensory cell cytosolic second-messenger concentrations within $30 \mathrm{sec}$ (Bernier et al., 1982), a time period well below the resolution of our perfusion system. Cyclic AMP is a second messenger that, in at least some cases, mediates the serotonergic modulation of voltage-gated channels in Aplysia. Preliminary experiments to ascertain whether cyclic AMP is the second messenger for the 5-HT-mediated augmentation of the ACh response indicate that cyclic AMP is not involved (work in progress). Another common second messenger for numerous cell functions is calcium. Kumamoto and Kuba (1983) have described a long-lasting enhancement of sympathetic ganglion cell $\mathrm{ACh}$ receptor sensitivity that is dependent upon cytosolic levels of calcium. Preliminary experiments in our laboratory do not implicate cytosolic calcium as a second messenger for the 5-HT-mediated enhancement of RB cell ACh responses (work in progress).

We do not know the cellular mechanism(s) underlying the 5-HT-induced enhancement of the RB cell ACh responses. Whether 5-HT is interacting with $\mathrm{RB}$ cell $\mathrm{ACh}$ receptors directly to facilitate the $\mathrm{ACh}$ response, or via a second messenger, remains to be resolved. We also do not know if 5-HT is (1) modulating the receptor-binding affinity of the channels for $\mathrm{ACh}$; (2) influencing ACh-channel kinetic and/or conductance parameters; and/or (3) modulating a secondary factor, i.e., rate of desensitization. Recent studies suggest that substance $P$ accelerates the desensitization process of ACh receptors in ganglion cells (Role, 1984) and chromaffin cells (Clapham and Neher, 1984). We have begun to address such questions using the "cellattached" patch clamp technique.

We observe a 5-HT-induced inward current at holding potentials more hyperpolarized (below $-40 \mathrm{mV}$ ) than the voltagedependent current described by Pellmar (1984). This small inward current appears to be a direct effect of 5-HT, since it was present when the preparation was maintained in a high-divalent cation ASW, as well as when the RB cell cluster was separated from the rest of the ganglion. Preliminary work indicates that this steady-state inward current is also voltage-dependent and requires $20-40 \mathrm{sec}$ to peak during a command pulse. Such a slow 5-HT current would not have been observed using Pellmar's protocol of presenting $2 \mathrm{sec}$ command pulses to voltageclamped RB cells.

With low concentrations (less than $10^{-5} \mathrm{M}$ ) of 5-HT, we can observe facilitation of the $\mathrm{ACh}$ response without observing the steady-state inward current. This suggests that there is some degree of independence between the mechanisms underlying the modulated $\mathrm{ACh}$ response and the inward current; the $\mathrm{ACh}$ response enhancement is not dependent upon net current flow through the ionic channels mediating the steady-state inward current.

Until recently, all molluscan synaptic contact was thought to occur in the neuropile, distant from the cell body. The transmitter-sensitive receptors on molluscan somas were considered an extrasynaptic curiosity. Now immunocytochemical studies at the light-microscopic level show serotonergic fibers in close proximity to various Aplysia cell bodies, including RB somas 
(Bailey et al., 1981; Goldstein et al., 1984; Kistler et al., 1985; Ono and McCaman, 1984; Schwartz and Shkolnik, 1981). These recent anatomical data suggest that somal receptors might have an important functional synaptic role in controlling overall cell activity.

In this paper, we have provided pharmacological evidence that 5-HT can modulate RB cell body excitatory ACh receptors. If this effect of 5-HT is physiological, it should be possible to identify serotonergic neurons that are presynaptic to the RB cells. One possible source of serotonergic input are the cells of the $\mathrm{RB}$ cluster, either via collaterals from one $\mathrm{RB}$ cell to another, or via RB cell collaterals onto themselves. We are also, at present, using the 5-HT-specific immunocytochemical map of Kistler et al. (1985) to test other possible candidate cells for direct serotonergic input onto RB cells. Whatever the modulatory role of 5-IIT receptors on RB cells, 5-HT may have an important integrative function in Aplysia that goes beyond the direct activation of 5-HT-sensitive ionic channels. Recently, Shozushima (1984) demonstrated that 5-HT can depress the response of dopaminergic receptors in RB cells. Serotonin, therefore, appcars to intcract with channels sensitive to other putative neurotransmitters, and, by enhancing the excitatory ACh input and depressing the inhibitory dopaminergic input, to effectively increase $\mathrm{RB}$ cell excitability.

\section{References}

Adams, W. B., and I. B. Levitan (1982) Intracellular injection of protein kinase inhibitor blocks the serotonin-induced increase in $\mathrm{K}^{+}$ conductance in Aplysia neuron R15. Proc. Natl. Acad. Sci. USA 79: 3877-3880.

Akasu, T., H. Keiji, and K. Koketsu (1981) 5-Hydroxytryptamine controls ACh-receptor sensitivity of bullfrog sympathetic ganglion cells. Brain Res. 211: 217-220.

Akasu, T., A. G. Karczmar, and K. Koketsu (1983) Effects of serotonin (5-hydroxytryptamine) on amphibian neuromuscular junction. Eur. J. Pharmacol. 88: 63-70.

Akopyan, A., N. K. Chemeris, V. I. Iljin, and B. N. Veprintser (1980) Serotonin, dopamine and intracellular cyclic AMP inhibit the responses of nicotinic cholinergic membrane in snail neurons. Brain Res. 201: 480-484.

Ascher, P. (1972) Inhibitory and excitatory effects of dopamine on Aplysia neurons. J. Physiol. (Lond.) 225: 173-209.

Ascher, P., A. Marty, and T. O. Neild (1978) Life time and elementary conductance of the channels mediating the excitatory effects of acetylcholine in Aplysia neurons. J. Physiol. (Lond.) 278: 177-206.

Bailey, C., R. Hawkins, M. Chen, and E. Kandel (1981) Interneurons involved in mediation and modulation of gill-withdrawal reflex in Aplysia. IV. Morphological basis of presynaptic facilitation. J. Neurophysiol. $45: 340-360$.

Bernier, L., V. F. Castellucci, E. R. Kandel, and J. H. Schwartz (1982) Facilitatory transmitter causes a selective and prolonged increase in adenosine $3^{\prime}: 5^{\prime}$-monophosphate in sensory neurons mediating the gill and siphon withdrawal reflex in Aplysia. J. Neurosci. 2: 1682-1691.

Brunelli, M., V. F. Castellucci, and E. R. Kandel (1976) Synaptic facilitation and behavioral sensitization in Aplysia: Possible role of serotonin and cAMP. Science 194: 1178-1181.

Castellucci, V. F., E. R. Kandel, J. H. Schwartz, A. C. Nairn, and P. Greengard (1980) Intracellular injection of the catalytic subunit of cAMP-dependent protein kinase stimulates facilitation of transmitter release underlying behavioral sensitization in Aplysia. Proc. Natl. Acad. Sci. USA 77: 7492-7496.

Castellucci, V. F., A. Nairn, P. Greengard, J. H. Schwartz, and E. R. Kandel (1982) Inhibition of adenosine $3^{\prime}: 5^{\prime}$ monophosphate dependent kinase blocks presynaptic facilitation in Aplysia. J. Neurosci. 2: 1673-1681.

Clapham, D. E., and E. Neher (1984) Substance P reduces acetylcholine-induced currents in isolated bovine chromaffin cells. J. Physiol. (Lond.) 347: 255-277.

Dreyer, F., K. Peper, and R. Sterz (1978) Determination of doseresponse curves by quantitative iontophoresis at the frog neuromuscular junction. J. Physiol. (Lond.) 281: 395-419.

Drummond, A. H., J. A. Benson, and I. B. Levitan (1980) Serotonin- induced hyperpolarization of an identified Aplysia neuron is mediated by cyclic AMP. Proc. Natl. Acad. Sci. USA 77: 5013-5017.

Dun, N. J., and A. G. Karczmar (1981) Evidence for a presynaptic inhibitory action of 5-hydroxytryptamine in a mammalian sympathetic ganglion. J. Pharmacol. Exp. Therapeut. 217: 714-718.

Dun, N. J., and R. C. Ma (1984) Slow non-cholinergic excitatory potentials in neurons of the guinea pig coeliac ganglia. J. Physiol. (Lond.) 351: 47-60.

Dun, N. J., M. Kiraly, and R. C. Ma (1984) Evidence for a serotoninmediated slow excitatory potential in the guinea-pig coeliac ganglia. J. Physiol. (Lond.) 351: 61-76.

Eisenstadt, M., J. E. Goldman, E. R. Kandel, H. Koike, J. Koester, and J. H. Schwartz (1973) Intrasomatic injection of radioactive precursors for studying transmitter synthesis in identified neurons of Aplysia californica. Proc. Natl. Acad. Sci. USA 70: 3371-3375.

Frazier, W. T., E. R. Kandel, I. Kupfermann, R. Waziri, and R. E. Coggeshall (1967) Morphological and functional properties of identified neurons in the abdominal ganglion of Aplysia californica. $\mathrm{J}$. Neurophysiol. 30: 1288-1351.

Fujimoto, D. (1976) Serotonin-sensitive aryl acylamidase activity of acetylcholinesterase. FEBS Lett. 71: 121-123.

Gerschenfeld, H. M., and D. Paupardin-Tritsch (1974a) Ionic mechanisms and receptor properties underlying the responses of molluscan neurons to 5-hydroxytryptamine. J. Physiol. (Lond.) 243: 427-456.

Gerschenfeld, H. M., and D. Paupardin-Tritsch (1974b) On the transmitter function of 5-hydroxytryptamine at excitatory and inhibitory monosynaptic junctions. J. Physiol. (Lond.) 243: 457-481.

Gerschenfeld, H. M., D. Paupardin-Tritsch, and P. Deterre (1981) Neuronal responses to serotonin: A second view. In Serotonin Neurotransmission and Behavior, B. L. Jacobs and A. Gelperin, eds., pp. 105-130, M.I.T., Cambridge, MA.

Goldstein, R., H. B. Kistler, Jr., H. W. M. Steinbusch, and J. H. Schwartz (1984) Distribution of serotonin-immunoreactivity in juvenile Aplysia. Neuroscience 11: 535-547.

Kandel, E. R., W. T. Frazier, R. Waziri, and R. E. Coggeshall (1967) Direct and common connections among identified neurons in Aplysia. J. Neurophysiol. 30: 1352-1376.

Kehoe, J. S. (1972) Three acetylcholine receptors in Aplysia neurons. J. Physiol. (Lond.) 225: 115-146.

Kistler, Jr., H. B., R. D. Hawkins, J. Koester, H. W. M. Steinbusch, E. R. Kandel, and J. H. Schwartz (1985) Distribution of serotoninimmunoreactive cell bodies and processes in the abdominal ganglion of mature Aplysia. J. Neurosci. 5: 72-81.

Klein, M., J. Camardo, and E. R. Kandel (1982) Serotonin modulates a specific potassium current in the sensory neurons that show presynaptic facilitation in Aplysia. Proc. Natl. Acad. Sci. USA 79: 57135717.

Koch, U. T., J. Koester, and K. R. Weiss (1984) Neuronal mediation of cardiovascular effects of food arousal in Aplysia. J. Neurophysiol. 51: $126-135$.

Koester, J., and E. R. Kandel (1977) Further identification of neurons in the abdominal ganglion of Aplysia using behavioral criteria. Brain Res. 121: 1-20.

Koketsu, K., T. Akasu, M. Miyagawa, and K. Hirai (1982) Modulation of nicotinic transmission by biogenic amines in bullfrog sympathetic ganglia. J. Auton. Nerv. Syst. 6: 47-53.

Kumamoto, E., and K. Kuba (1983) Sustained rise in ACh sensitivity of a sympathetic ganglion cell induced by postsynaptic electrical activities. Nature 305: 145-146.

Liebeswar, G., J. E. Goldman, J. Koester, and E. Mayeri (1975) Neural control of circulation in Aplysia. III. Neurotransmitters. J. Neurophysiol. 38: 767-779.

Mandelbaum, D. E., J. Koester, M. Schonberg, and K. R. Weiss (1979) Cyclic AMP mediation of the excitatory effect of serotonin in the heart of Aplysia. Brain Res. 177: 388-394.

North, R. A., G. Henderson, Y. Katayama, and S. M. Johnson (1980) Electrophysiological evidence for presynaptic inhibition of acetylcholine release by 5 -hydroxytryptamine in the enteric nervous system. Neuroscience 5: 581-586.

Ono, J. K., and R. E. McCaman (1984) Immunocytochemical localization and dircct assays of scrotonin-containing ncurons in Aplysia. Neuroscience 11: 549-560.

Pellmar, T. C. (1981) Does cyclic 3',5'-adenosine monophosphate act as second messenger in a voltage-dependent response to 5-hydroxytryptamine in Aplysia? Br. J. Pharmacol. 74: 747-756. 
Pellmar, T. C. (1984) Enhancement of inward current by serotonin in neurons of Aplysia. J. Neurobiol. 15: 13-25.

Pellmar, T. C., and D. O. Carpenter (1980) Serotonin induces a voltage-sensitive calcium current in neurons of Aplysia californica. J. Neurophysiol. 44: 423-439.

Pollock, J. D., L. Bernier, and J. S. Camardo (1985) Serotonin and cyclic adenosine $3^{\prime}: 5^{\prime}$-monophosphate modulate the $S$ potassium current in tail sensory neurons in the pleural ganglion of Aplysia. J. Neurosci. 5: 1862-1871.

Ram, J. L., D. Gole, V. Shukla, and L. Greenberg (1981) Serotoninactivated adenylate cyclase and the possible role of cyclic AMP in modulation of buccal muscle contraction in Aplysia. J. Neurobiol. 14: 113-121.

Role, L. W. (1984) Substance P modulation of acetylcholine-induced currents in embryonic chicken sympathetic and ciliary ganglion neurons. Proc. Natl. Acad. Sci. USA 81: 2924-2928.

Sawada, M., M. Ichinose, I. Ito, T. Maeno, and D. J. McAdoo (1984) Effects of 5-hydroxytryptamine on membrane potential, contractility, accumulation of cyclic AMP, and $\mathrm{CA}^{2+}$ movements in anterior aorta and ventricle of Aplysia. J. Neurophysiol. 51: 361-374.

Schwartz; J. H., and L. J. Shkolnik (1981) The giant serotonergic neuron of Aplysia: A multi-targeted cell. J. Neurosci. 1: 606-619.

Segal, M. M., and J. Koester (1982) Convergent cholinergic neurons produce similar postsynaptic actions in Aplysia: Implications for neural organization. J. Neurophysiol. 47: 742-759.

Shozushima, M. (1984) Blocking effect of serotonin on inhibitory dopamine receptor activity of Aplysia ganglion cells. Jpn. J. Physiol. 34: 225-243.

Shuster, M. J., J. S. Camardo, S. A. Siegelbaum, and E. R. Kandel (1985) Cyclic AMP-dependent protein kinase closes the serotonin-

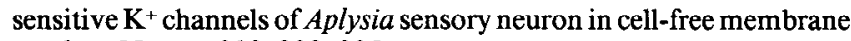
patches. Nature 313: 392-395.

Siegelbaum, S. A., J. S. Camardo, and E. R. Kandel (1982) Serotonin and cyclic AMP close single $\mathrm{K}^{+}$channels in Aplysia sensory neurons. Nature 299: 413-417.

Simmons, L. K. (1983) Preliminary characterization of excitatory acetylcholine receptors in Aplysia using the single channel recording technique. Soc. Neurosci. Abstr. 9: 457.

Simmons, L. K. (1984) Serotonin enhances the response of excitatory acetylcholine receptors in the RB cell cluster of Aplysia californica. Soc. Neurosci. Abstr. 10: 5.

Tremblay, J. P., P. Woodson, W. T. Schlapfer, and S. H. Barondes (1976) Dopamine, serotonin and related compounds: Effects on synaptic depression, frequency facilitation, and post-tetanic potentiation at a synapse in Aplysia californica. Brain Res. 109: 61-81.

Wallis, D. I. and B. Woodward (1975) Membrane potential changes induced by 5 -hydroxtryptamine in the rabbit superior cervical ganglion. Br. J. Pharmacol. 55: 199-212.

Walsh, J. P., and J. H. Byrne (1985) Analysis of decreased conductance serotonergic response in Aplysia ink motor neurons. J. Neurophysiol. 53: 590-602.

Weiss, K. R., J. L. Cohen, and I. Kupfermann (1978) Modulatory control of buccal musculature by a serotonergic neuron (metacerebral cell) in Aplysia. J. Neurophysiol. 41: 181-203.

Weiss, K. R., D. E. Mandelbaum, M. Schonberg, and I. Kupfermann (1979) Modulation of buccal muscle contractility by serotonergic metacerebral cells in Aplysia: Evidence for a role of cyclic adenosine monophosphate. J. Neurophysiol. 42: 791-803. 